\title{
NOMENCLATURAL NOTES ON PTEROGONIUM (BRYOPHYTA, LEUCODONTACEAE)
}

\author{
RYSZARD OCHYRA ${ }^{1}$ \& HALINA BEDNAREK-OCHYRA
}

\begin{abstract}
A taxonomic and nomenclatural history of the moss genus Pterogonium Sw. is outlined and the illegitimacy of this name is confirmed. Nogopterium Crosby \& W. R. Buck, the name of a new genus erected to replace the illegitimate Pterogonium, is accepted as validly published. This genus consists of five species, two of which, N. coreense (Cardot) Tad. Suzuki and N. tenellum (Tad. Suzuki \& Z. Iwats.) Tad. Suzuki, have only recently been transferred to this genus. The transfer of the fifth species, $N$. tsilingense (P. C. Chen) Tad. Suzuki ex Ochyra \& Bedn.-Ochyra, comb. nov., is effected in the present account.
\end{abstract}

Key words: Asia, illegitimate names, Japan, Musci, Nogopterium, nomenclature, Pterigynandrum, taxonomy

Ryszard Ochyra \& Halina Bednarek-Ochyra, Department of Bryology, W. Szafer Institute of Botany, Polish Academy of Sciences, ul.Lubicz 46,31-512 Kraków,Poland; e-mail: r.ochyra@botany.pl \& h.bednarek@botany.pl

The moss genus Pterogonium Sw. was described by Swartz (1799: 12, 26-27), but as a pre-startingpoint name, which for Musci (except Sphagnaceae) is conventionally fixed for 1 January 1801 (McNeill et al. 2012), it was not validly published. A single species, $P$. gracile Sw., was included in the genus, but 'Pterigynandrum H.[edwig]' was also parenthetically cited as a synonym. The generic name Pterogonium was validated in an anonymous review published on 1 June 1801 in Monthly Review (Anonymous 1801). Yet it was illegitimate when published, as Pterigynandrum Hedw. was included as a synonym. The latter is also a pre-starting-point name, but it was validated on 1 January 1801 in Species muscorum frondosorum (Hedwig 1801). Three species were included in Pterigynandrum, namely $P$. gracile Hedw., $P$. julaceum Hedw. and P. filiforme Hedw., but none was indicated as type. As no type of Pterogonium was indicated it is automatically typified by the type of Pterigynandrum, when such a type is selected.

Despite its illegitimacy, Pterogonium has gained wide acceptance. The genus was soon redescribed by Smith (1802), who, in English botany, placed in it two species, $P$. gracile (Hedw.) Sm.

\footnotetext{
1 Corresponding author
}

and Hypnum smithii Dicks. ex Hedw. This concept was repeated two years later by Smith (1804) in his Flora britannica; the only difference was the formal transfer of $H$. smithii to Pterogonium as $P$. smithii (Hedw.) Sm. In the nineteenth century no less than 32 Pterogonium species were described as new to science from throughout the world and, additionally, about 40 species were transferred to this genus (Wijk et al. 1967, 1969). However, in modern moss taxonomy they correctly belong to a number of distantly related genera, including Entodon Müll. Hal., Erythrodontium Hampe, Fabronia Raddi, Forsstroemia Lindb., Glyphothecium Hampe, Habrodon Schimp., Heterocladium Schimp., Leptohymenium Schwägr., Leskea Hedw., Leskeella (Limpr.) Loeske, Leucodon Schwägr., Lindbergia Kindb., Meiothecium Mitt., Myurella Schimp., Platygyrium Schimp., Regmatodon Brid., Schwetschkea Müll. Hal., Scorpiurium Schimp., Trachyphyllum Gepp, and others.

The modern concept of Pterigynandrum and Pterogonium was outlined by Schimper (1851a, b), who considered them to be distinct monotypic genera. He very clearly designated Pterigynandrum filiforme as the type of Pterigynandrum (Schimper 1851a: 121 ['… eine strengere Würdigung des Fruchtstandes und Blattzellnetzes führte uns aber 
nothwendigerweise zu einer Trennung und veranlasst und Pt. filiforme als Typus einer neuen Gattung aufzustellen.']) and Pterogonium gracile as the type of Pterogonium (Schimper 1851a: 125 ['Wir glauben jede dieser beiden Arten \{i.e., Pterigynandrum gracile and $P$. filiforme zum Typus einer eigenen Gattung machen zu müssen, um so jede ezwungene Vereinigung zu vermeiden.']), and this concept of the two genera has been widely adopted by bryologists. However, our rules make this latter designation ineffective under the provisions of Art. 7.5 of the current Code (McNeill et al. 2012), because Pterogonium is automatically typified by the type of Pterigynandrum, that is, $P$. filiforme.

The illegitimacy of Pterogonium has long been overlooked; this name has consistently been used in Floras, catalogues, checklists and atlases of mosses, including Index muscorum (Wijk et al. 1967), Index nominum genericorum (plantarum) (Farr et al. 1979) and Names in current use for extant plant genera (Greuter et al. 1993). Since the Paris Code (Lanjouw et al., 1956), Pterogonium, along with Pterigynandrum and Leptohymenium Schwägr., was included in the list of generic names against which Platygyrium Schimp. was conserved. The last time it appeared in that list was in the Tokyo Code (Greuter et al. 1994), but from the Saint Louis Code (Greuter et al. 2000) onward it has been editorially deleted, doubtless because its illegitimacy was noted. Accordingly, the relevant entry for Pterogonium has been corrected in the online edition of Index nominum genericorum (plantarum) (http://botany.si.edu/ing/ genusSearchTextMX.cfm).

It is worth noting that Balsamo and De Notaris (1834: 110) established the family Pterogoniaceae (as ordo Pterogonoideae); this name was formed from the generic name Pterogonium. However, this name is illegitimate because, under Art. 18.3 of the Melbourne Code (McNeill et al. 2012), it was based on the illegitimate generic name. Otherwise it would be the oldest available name for the family Leucodontaceae Schimp. which was established more than two decades later (Schimper 1860) and is in current use (Ochyra et al. 2003; Goffinet et al. 2009). Interestingly, Schimper
(1860: 507) also recognised the separate family Pterogoniaceae Schimp. nut this name has to be considered as a later isonym of the Pterogoniaceae Balsamo \& De Not.

In such a situation, a proposal to conserve Pterogonium with a conserved type, to retain the hitherto existing application of this name, would then have been the simplest way to maintain its use, in accordance with the provisions of Pre. 1 and Art. 14.1-2 of the then-operating Vienna Code (McNeill et al. 2006). Indeed, Pekka Isoviita, Helsinki (personal communication) intended to submit such a proposal; unfortunately, his death prevented fulfilment of his intent. Instead, Crosby and Buck (2011) published the generic name Nogopterium Crosby \& W. R. Buck as a 'replacement' of Pterogonium sensu Schimper (1876). This new name gained acceptance in some recent moss Floras (e.g., Bourell 2014; Hedenäs \& Hallingbäck 2014; Fuertes \& Oliván 2014) and catalogues (e.g., Hodgetts 2015; Erdağ \& Kürschner 2017), so that it is now doubtful that a belated proposal to conserve Pterogonium would be recommended by the Committee for Bryophyta.

Nevertheless, the publication of 'Nogopterium Crosby \& W. R. Buck, nom. nov., pro Ptergonium sensu Schimp., Syn. Musc. Eur., ed. 2, 575. 1876.' needs some comment. Nogopterium is not a 'nom. nov.', as it is based on a later (mis)application of the illegitimate name Ptergonium, but is technically the name of a new genus. As stated by its authors, the name was validly published, in compliance with Art. 38.13 of the current Code (McNeill et al. 2012), by a full and direct reference to Schimper's (1876: 575) Latin description of the Pterogonium: 'The following new generic name, to be pronounced no-gop-te'r-i-um, is validated under Article 32.1(d) of the Vienna Code (McNeill et al., 2006: 58) by reference to a previously and effectively published description'. Moreover, as mandated by Art. 40.3 of the Code (McNeill et al. 2012), the type was stated to be Nogopterium gracile (Hedw.) Crosby \& W. R. Buck.

Crosby and Buck (2011) considered Nogopterium to be a bitypic genus, consisting of $N$. gracile (Hedw.) Crosby \& W. R. Buck and a poorly known species from Brazil, N. beyrichianum (Hampe) 
Crosby \& W. R. Buck. Subsequently, Suzuki and Iwatsuki (2012) described one new species of Pterogonium from Japan and included in it two other Asian species. However, Suzuki's (2016) attempt to transfer these three names to Nogopterium was only partly correct.

There is no validation of any new combination in Nogopterium on p. 138 of Suzuki's (2016) Revised New Catalog, but an explicit, full and direct reference appears under the basionym entry on pages 166 and 167 for both $P$. coreense Cardot and $P$. tenellum Tad. Suzuki \& Z. Iwats., and this suffices to validate the new combinations under $\mathrm{No}$ gopterium. On page 138, Suzuki (2016) ascribed all Nogopterium binomials to 'Crosby \& W. R. Buck' but this pre-ex citation should be omitted from the author citation, as it does not appear on pages 166 and 167 (even on page 138 it might be dismissed as a 'formal error' under Art. 46.3 of the Code).

The third species, Pterogonium tsilinengense (P. C. Chen) Tad. Suzuki \& Z. Iwats. was validly published at species rank in the 2012 paper (Suzuki \& Iwatsuki 2012). However, the combination Nogopterium tsilinengense was not validly published by a full and direct reference to it on p. 167 of the Revised New Catalog (Suzuki 2016), because, in compliance with Art. 41.7 of the current Code (McNeill et al. 2012), it is not the basionym of the intended new combination. So that combination is made herein.

The correct authorships of the names of the remaining three species of Nogopterium and basionyms are as follows:

\section{Nogopterium coreense (Cardot) Tad. Suzuki}

Hattoria 7: 166. June 2016.

Basionym: Pterogonium coreense Cardot, Beih. Bot. Centralbl. 12: 23, f. 14. 18 Oct 1904.

Nogopterium tenellum (Tad. Suzuki \& Z. Iwats.) Tad. Suzuki

Hattoria 7: 166. June 2016.

BAsionym: Pterogonium tenellum Tad. Suzuki \& Z. Iwats., Hattoria 3: 57, f. 1, 5a. May 2012.

Nogopterium tsilingense (P. C. Chen) Tad. Suzuki ex Ochyra \& Bedn.-Ochyra, comb. nov.
BASIONYM: Pterogonium gracile (Hedw.) Sm. var. tsilingense P. C. Chen, Acta Phytotax. Sin. 12: 247. 1974 $\equiv$ P. tsilingense (P. C. Chen) Tad. Suzuki \& Z. Iwats., Hattoria 3: 59, f. 3, 5c. May 2012.

ACKNowledgemEnTs. Special thanks are due to Professors Werner Greuter (Berlin) and John McNeill (Edinburgh) for their valuable suggestions and comments, and to Rod D. Seppelt (Arundel, Australia) for checking the English. This study received financial support from the statutory fund of the W. Szafer Institute of Botany of the Polish Academy of Sciences.

\section{REFERENCES}

AnONymous 1801. [Review of] Olaf Swartz, Med. Doct. \& $c$. \& c. \& c. Dispositio systematica muscorum frondosorum Sueciae, adjectis descriptionibus et iconibus novarum specierum. 12mo. pp. 112. Erlangae, apud Io. Jac. Palm. 1799. Monthly Rev., ser. 2 34: 535-538.

Balsamo J. \& De Notaris J. 1834. Prodromus bryologiae mediolanensis. Ex Typographia Felicis Rusconi, Mediolani.

Bourell M. 2014. Nogopterium Crosby \& W. R. Buck. In: Flora of North America Editorial Committee (ed.), Flora of North America north of Mexico. 28 Bryophyta, part 2, pp. 595-596. Oxford University Press, New York and Oxford.

Crosby M. R. \& Buck W. R. 2011. Nogopterium, a new name for the genus Pterogonium (Musci, Leucodontaceae). Novon 21: 424-425.

ERDAĞ A. \& KÜRSCHNER H. 2017. Türkiye bitkileri listesi (Karayosunlart). ANG Vakfi - Nezahat Gökyiğ Botanik Bahçesi, İstanbul.

Farr E. R., Leussink J. A. \& Stafleu F. A. (eds) 1979. Index nominum genericorum (plantarum). 3. Pegaeophyton $-Z y$ zygium. Regnum Vegetabile 102. Bohn, Scheltema \& Holkema, Utrecht and dr. W. Junk b.v., Publishers, The Hague.

Fuertes E. \& Oliván G. 2014. Leucodontaceae. In: J. Guerra, M. J. CANO \& M. BRUGUÉs (eds), Flora briofitica ibérica. 5. Orthotrichales: Orthotrichaceae; Hedwigiales: Hedwigiaceae; Leucodontales: Fontinalaceae, Climaciaceae, Anomodontaceae, Cryphaeaceae, Leptodontaceae, Leucodontaceae, Neckeraceae; Hookeriales: Hypopterygiaceae, Hookeriaceae, Leucomiaceae, Pilotrichaceae, pp. 191-201. Universidad de Murcia, Sociedad Española de Briología, Murcia.

Goffinet B., Buck W. R. \& Shaw A. J. 2009 ['2008']. Morphology, anatomy, and classification of the Bryophyta. In: B. Goffinet \& A. J. Shaw (eds), Bryophyte biology. Second edition, pp. 55-138. Cambridge University Press, Cambridge.

Greuter W., Brummitt R. K., Ellen F., Kilian N., Kirk P. M. \& Silva P. C. (eds) 1993. Names in current use for extant 
plant genera. Regnum Vegetabile 129. Koeltz Scientific Books, Königstein.

Greuter W., Barrie F. R., Burdet H. M., Chaloner W. G., Demoulin V., Hawksworth D. L., Jørgensen P. M., Nicolson D. H., Silva P. C., Trehane P. \& MCNeILl J. 1994. International Code of Botanical Nomenclature (Tokyo Code) adopted by the Fifteenth International Botanical Congress, Yokohama, August-September 1993. Regnum Vegetabile 131. Koeltz Scientific Books, Königstein.

Greuter W., McNeill J., Barrie F. R., Burdet H. M., Demoulin V., Filgueiras T. S., Nicolson D. H., Silva P. C., Skog J. E., Trehane P., Turland N. J. \& Hawksworth D. L. 2000. International Code of Botanical Nomenclature (Saint Louis Code) adopted by the Sixteenth International Botanical Congress, St Louis, Missouri, July-August 1999. Regnum Vegetabile 138. Koeltz Scientific Books, Königstein.

HedenÄS L. \& HallingBäcK T. 2014. Nationalnyckeln till Sveriges flora och fauna. Bladmossor: Skirmossor-baronmossor. Bryophyta: Hookeria-Anomodon. ArtDatabanken, Sveriges lantbruksuniversitet, Uppsala.

HedwIG J. 1801. Species muscorum frondosorum descriptae et tabulis aeneis LXXVII coloratis illustratae. Sumtu Joannis Ambrosii Barthii, Lipsiae and apud Amand Koenig, Parisiis.

Hodgetts N. G. 2015. Checklist and country status of European bryophytes - towards a new Red List for Europe. Irish Wildlife Manuals 84: 1-125.

Lanjouw J., Baehni Ch., Robyns W., Rollins R. C., Ross R., Rousseau J., Schulze G. M., Smith A. C., Vilmorin R. DE \& STAFLEU F. A. 1956. International Code of Botanical Nomenclature adopted by the Eighth International Botanical Congress, Paris, July 1954. Regnum Vegetabile 8. International Bureau for Plant Taxonomy and Nomenclature of the International Association for Plant Taxonomy, Utrecht.

McNeill J., Barrie F. R., Burdet H. M., Demoulin V., Hawksworth D. L., Marhold K., Nicolson D. H., Prado J., Silva P. C., Skog J. E., Wiersema J. H. \& Turland N. J. (eds). 2006. International Code of Botanical Nomenclature (Vienna Code), adopted by the Seventeenth International Botanical Congress Vianna, Austria, July 2005. Regnum Vegetabile 146. A. R. G. Gantner Verlag, Ruggell, Lichtenstein.

McNeill J., Barrie F. R., Buck W. R., Demoulin V., Greuter W., Hawksworth D. L., Herendeen P. S., Knapp S., Marhold K., Prado J., Prud'homme van Reine W. F., Smith G. F., Wiersema J. H. \& Turland N. J. (eds) 2012. International Code of Nomenclature for algae, fungi, and plants (Melbourne Code), adopted by the Eighteenth International Botanical Congress Melbourne, Australia, July 2011. Regnum Vegetabile 154. Koeltz Scientific Books, Königstein.
Ochyra R., Żarnowiec J. \& BednareK-Ochyra H. 2003. Census catalogue of Polish mosses. Polish Academy of Sciences, Institute of Botany, Kraków.

SCHIMPer W. PH. 1851a. Pterigynandrum. In: W. PH. SCHIMPer (ed.), Bryologia europaea seu genera muscorum europaeorum monographicae illustrata. 5: 119-122 + pl. 466 [Fasc. 46-47: 4 pp. + 1 pl.]. Sumptibus Librariae E. Schweizerbart, Stuttgartiae.

Schimper W. Ph. 1851b. Pterogonium. In: W. Ph. Schimper (ed.), Bryologia europaea seu genera muscorum europaeorum monographicae illustrata. 5: 123-126+ pl. 467 [Fasc. 46-47: 4 pp. +1 pl.]. Sumptibus Librariae E. Schweizerbart, Stuttgartiae.

SCHIMPER W. PH. 1856 ['1855']. Corollarium bryologiae europaeae, conspectum diagnosticum familiarum, generum et specierum, adnotationes novas atque emendationes complectens. Sumptibus librariae E. Schweizerbart, Stuttgartiae.

SCHIMPER W. PH. 1860. Synopsis muscorum europaeorum praemissa introductione de elementis bryologicis tractante. Sumptibus Librariae E. Schweizerbart, Stuttgart.

SCHIMPER W. PH. 1876. Synopsis muscorum europaeorum praemissa introductione de elementis bryologicis tractante. 2. Specierum descriptio. Sumptibus librariae E. Schweizerbart (E. Koch), Stuttgartiae.

Sмiтh J. E. 1802. Pterogonium gracile. Slender Pterogonium. In: J. E. SмITH, English botany; or coloured figures of British plants, with their essential characters, synonyms, and places of growth. 16: pl. 1085. Printed by Wilks and Taylor, London.

Sмiтh J. E. 1804. Musci. In: J. E. Sмiтh, Flora britannica. 3: 1099-1383 + 1405-1406 (Addenda et corrigenda). Typis J. Davis, Londini.

SUZUKI T. 2016. A revised new catalog of the mosses of Japan. Hattoria 7: 9-223.

Suzuki T. \& Iwatsuki Z. 2012. Notes on Leucodontaceae (I). Gen. Pterogonium Sw. newly found in Japan. Hattoria 3: 57-66.

Swartz O. 1799. Dispositio systematica muscorum frondosorum Sueciae, adjectis descriptionibus et iconibus novarum specierum. Apud Ioannem Jacobum Palm, Erlangae.

Wijk R., van der, Margadant W. D. \& Florschütz P. A. 1962. Index muscorum. 4 (P-S). Regnum Vegetabile 48. International Bureau for Plant Taxonomy and Nomenclature of the International Association of Plant Taxonomy, Utrecht.

Wijk R., van der, Margadant W. D. \& Florschütz P. A. 1969. Index muscorum. 5 (T-Z, Appendix). Regnum Vegetabile 65. International Bureau for Plant Taxonomy and Nomenclature of the International Association of Plant Taxonomy, Utrecht. 